\title{
ビデオ画像を用いたボート漕法の動的解析
}

\section{Dynamic Analysis of Boat Rowing using Video Imagery}

\author{
近 津 博 文*，村井俊治** \\ Hirofumi CHIKATSU, Shunii MURAI
}

\begin{abstract}
The video imagery gives important information to the dynamic analysis of human motion in the field of sports training or rehabilitation. For understanding the dynamics of human motion from image sequences, however, there are two complicated subjects. One is an image processing, for example, automated recognition of human's feature points such as head, shoulder, elbow, knee etc.. The second is, how to estimate the camera parameter in the photogrammetry.

This paper presents a method to estimate the camera parameter, and shows the results of dynamic analysis in the case of boat rowing. In this study, the bow and no. 2, gold medalists in the Canadian eight team on the Barcelona olympic games at 1992 were selected.
\end{abstract}

\section{1.はじめに}

ビデオカメラの利用はスポーツ時の障害防止，技術 の向上あるいは歩行訓練におけるリハビリテーション 等スポーツおよび医学の分野における人体の動作解析 に極めて有効な情報を提供するものと期待される。し かし，ビデオ画像の有効利用の為には解決されなけれ ばならない二つの問題が含まれている。一つは画像処 理であり, 連続画像からの人体の動きの検出, 特に肘, 膝等の人体の特徵点の自動的抽出が問題となる。筆者 等は人体および輪郭などの特徵情報を利用した画像処 理により1991年 8 月，東京で開催された世界陸上選手 権 $100 \mathrm{~m}$ 競技におけるカール・ルイスの特徵点抽出を 行なった1)。その結果さらに高次元での画像処理技術 が課題となった。ノイズ部分での輪郭の検出 ${ }^{23)}$, コン ピューターグラフィックやアニメーション技術の利 用 4 )5)等, 特徴点の自動抽出のためには画像処理技術だ けでなくパターン認識, コンピューターグラフィック, アニメーション技術さらには人工知能とを結合した技

* 東京電機大学理工学部建設工学科

** アジア工科大学院（東京大学生産技術研究所）

「写真測量とリモートセンシング」Vol. 32,No. 3，1993
術が必要とされる6)。

従来の動作解析は一般的に固定されたカメラの視準 範囲の中において行なわれてきた7)8)。したがって，力 メラキャリブレーションを予め行なうことが可能であ る。しかし，一般的に撮影されたビデオ画像あるいは TV 画像を利用した動作解析を考慮すると，これらの 画面には基準点等は存在せず，またカメラに対する情 報が得られない場合，さらに物体の移動とともにカメ ラも移動するような場合（カール・ルイスの動作解析 においてはカメラの位置は固定されており回転角が未 知量であった。）もありカラの標定要素をいかに定め るかが二つめの問題となる。

本研究では, 上記二番目のカメラの標定問題を取り 上げ，物体の移動とともにカメラの位置および回転角 も変化する例としてバルセロナ・オリンピック（1992 年）でのエイト競技の画像から優勝チーム・カ十ダの バウ (船首の漕ぎ手) と 2 番に対する一本（一漕ぎ） 分の動作解析を行なった。なお，本研究では特徵点の 抽出はマニュアルで行なった。

\section{2. カメラの標定}

本研究で使用した画像データは TV 放送用に撮影 されたもので，撮影カメラはボートと共に移動し，ま 
た TV 観戦者のために撮影アングルおよびフォ一カ スが常に変化している。画面には基準点は存在しない。 さらに，国外での撮影のため使用カメラの同定ができ ず，ビデオカメラのキャリブレーションにおける焦点 距離およU゙スケールファクター等の初期值が設定され ない等極めて悪条件下での画像である。

本研究においては画面に見られるコースおよびコー ス幅用のブイを基準点として利用することとし，各ブ イの間隔をボートおよびオールの長さ等との関係から コース間隔 (横方向) $5 \mathrm{~m}$ およびコース幅間隔 $10 \mathrm{~m}$ と する。しかし，ズーム画面にはブイが入らず，ワイド 画面には多くのブイがあるものの人物が小さすぎて例 えマニュアルでも特徵点の抽出は不可能であり, 約 5 分30秒間のレース中で動作解析に使用出来そうな画面 は1400m (3'47.433"；困 $1 \sim 3^{\prime} 49.066^{\prime \prime}$ ；困 2 ) 付近て の約一本分である。闵 1 から 2 のわずか約 1.6 秒の間に もフォ一カスが変化していることが認められる。

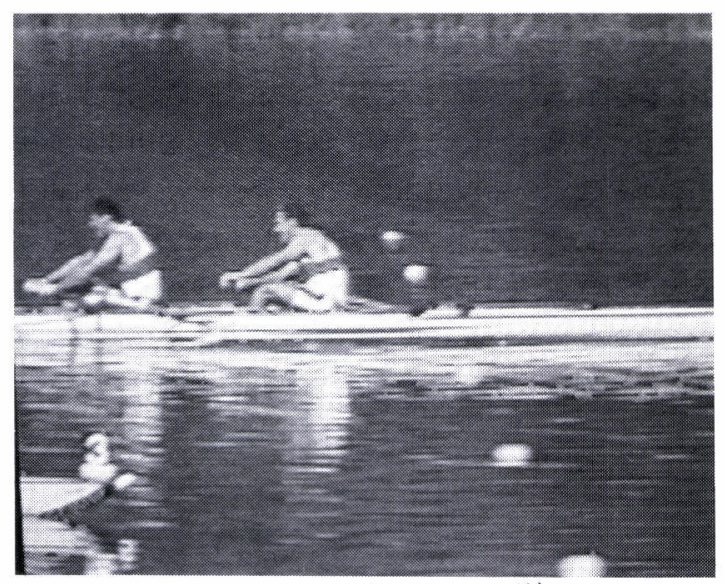

図 1 標定画像（３分47.433秒）

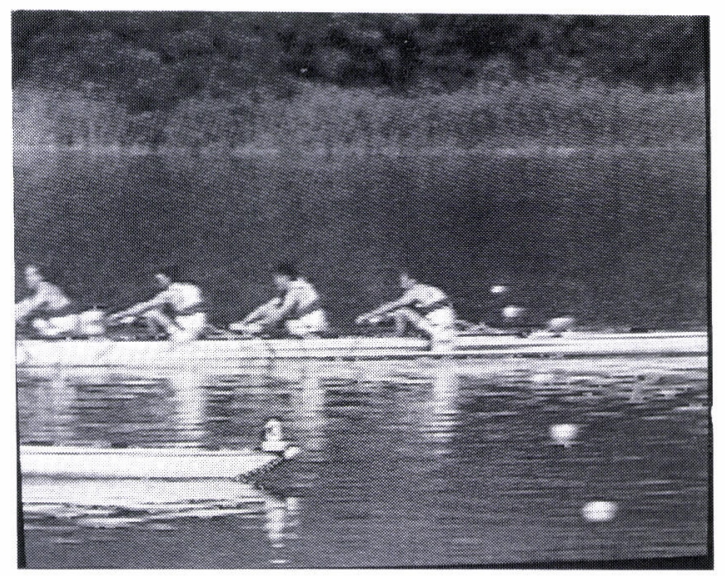

図2 標定画像 ( 3 分49.066秒)
単䒓真標定では次の共線条件式が観測方程式とな る。

$$
\begin{aligned}
& x=-f \frac{a_{11}\left(X-X_{o}\right)+a_{12}\left(Y-Y_{o}\right)+a_{13}\left(Z-Z_{o}\right)}{a_{31}\left(X-X_{o}\right)+a_{32}\left(Y-Y_{o}\right)+a_{33}\left(Z-Z_{o}\right)} \\
& y=-f \frac{a_{21}\left(X-X_{o}\right)+a_{22}\left(Y-Y_{o}\right)+a_{23}\left(Z-Z_{o}\right)}{a_{31}\left(X-X_{o}\right)+a_{32}\left(Y-Y_{o}\right)+a_{33}\left(Z-Z_{o}\right)}
\end{aligned}
$$

ここに，(x,y)；写真座標

$(X, Y, Z)$ ；地上座標

$\left(X_{o}, Y_{o}, Z_{o}\right)$; 撮影点の地上座標

$\omega, \phi, x$; 力メラ軸の回転角

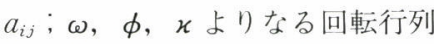

$f$; 焦点距離

しかし，汹1および 2 においてもハレーションが認 められるブイが画面上に一列存在するのみで, 標定計 算は極女て不安定となる。本研究では $\phi=0^{\circ}$ と仮定 し, $\omega, \varkappa, f, X_{o}, Y_{o}, Z_{0}$ の 6 個を未知量とした。

標定計算の実行に当たっては，まずカメラ位置と焦 点距離の初期值を任意に与之, 収束解が得られる各初 期值の範囲を求める。この場合, 標定結果は焦点距離 の初期值により異なる。そこで, 本研究では本解析に 使用した一本分以外の画面に撮影されているカメラと 人との位置から推定されるカメラ高 $3.2 \mathrm{~m}$ を考慮し て, 焦点距離の初期值を変化させて算出される 6 個 $\left(\omega, \boldsymbol{\kappa}, f, X_{o}, Y_{o}, Z_{o}\right)$ の標定要素の内, $3.2 \mathrm{~m}$ に近 い $Z_{0}$ が得られた場合を標定結果として採用する $\left(Z_{o}=3.2 \mathrm{~m}\right.$ と固定させる方法も一つの手段である が, 本研究ではこの值は, 標定結果採用の判断の基準 にとどめた)。なお, 算出された各要素を用いて各基準 点に対して式(1)より $Z=0$ として導かれる次式

$$
\begin{aligned}
& X=X_{o}-Z_{o} \frac{a_{11} x+a_{21} y-a_{31} f}{a_{13} x+a_{23} y-a_{33} f} \\
& Y=Y_{o}-Z_{o} \frac{a_{12} x+a_{22} y-a_{32} f}{a_{13} x+a_{23} y-a_{33} f}
\end{aligned}
$$

から計算される座標值と予め定めた座標値（図 3) と の平均二乗誤差 (写真 $1 ； \sigma_{x y}=0.118 \mathrm{~m}$, 写真 2 ; $\left.\sigma_{x y}=0.102 \mathrm{~m}\right)$ は焦点距離に左右されず，推定された カメラモデルから十分に対象平面が再現されると判断 されるため焦点距離の厳密解に拘束される必要はな い。困 3 に図 1 および 2 における座標系を示す。

表一 1 は四 1 および 2 に対するキャリブレーション の結果である。四 3 に図 1 ，2 2 対するカメラの位置 


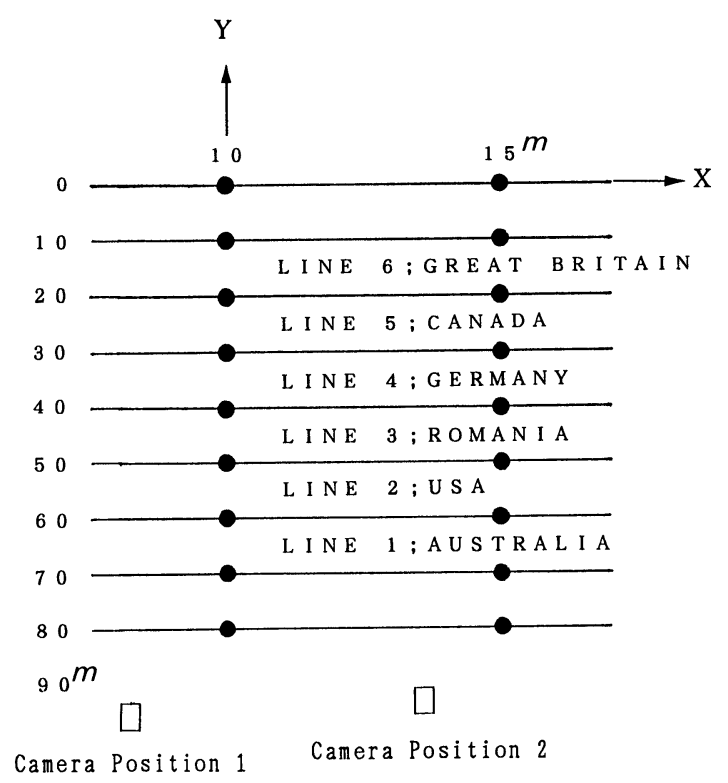

図 3 標定画像における地上座標

表 1 標定結果

\begin{tabular}{ccccc}
\hline \multicolumn{3}{c}{ 図 1} & \multicolumn{3}{c}{ 目 2} \\
\hline$\omega ;$ & $87^{\circ} 14^{\prime} 16.7^{\prime \prime}$ & $\left(0.5816^{\circ}\right)$ & $87^{\circ} 18^{\prime} 44.2^{\prime \prime}$ & $\left(0.3464^{\circ}\right)$ \\
$\phi ;$ & $0^{\circ} 0^{\prime} 00^{\prime \prime}$ & & $0^{\circ} 0^{\prime} 00^{\prime \prime}$ & \\
$\mathcal{\varkappa} ;$ & $-1^{\circ} 0^{\prime} 37.2^{\prime \prime}$ & $\left(0.5820^{\circ}\right)$ & $0^{\circ} 43^{\prime} 33.0^{\prime \prime}$ & $\left(0.3465^{\circ}\right)$ \\
$X_{o} ;$ & $8.253 \mathrm{~m}$ & $(0.1448 \mathrm{~m})$ & $13.521 \mathrm{~m}$ & $(0.0857 \mathrm{~m})$ \\
$Y_{o} ;$ & $90.687 \mathrm{~m}$ & $(0.4339 \mathrm{~m})$ & $90.364 \mathrm{~m}$ & $(0.2500 \mathrm{~m})$ \\
$Z_{o} ;$ & $3.132 \mathrm{~m}$ & $(0.4077 \mathrm{~m})$ & $3.287 \mathrm{~m}$ & $(0.2458 \mathrm{~m})$ \\
$f ; 2200.395 \mathrm{~mm}$ & $(0.7122 \mathrm{~mm})$ & $1499.921 \mathrm{~mm}$ & $(0.3502 \mathrm{~mm})$ \\
\hline
\end{tabular}

ただし, ( ) ; RMS

を示す。

一方，図 1 と 2 の間(約1.6秒間)では $\omega, \kappa, f, X_{o}$, $Y_{o}, Z_{o}$ は直線的に変化するものと仮定し, 一本分の各 画面に対するこれらの未知数を定める。

\section{3.人体の特徵点位置の解析}

各特徵点は完全な動作の繰り返しが行なわれるもの として 3 分 47.4 秒から 3 分 48.9 秒迄の 45 画面を一本分 とした。また，本研究で動作解析の対象とする人体の 特徵点は頭, 首, 肩, 肘 (左右), グリップ (左右), 背中，膝，シートおよび踵の11点である。これらの各 特徴点に対する平面座標 $\left(X^{\prime}, Y^{\prime}\right)$ はカメラの位置か らボートが走行している平面までの距離は一定である こと（図 4 ) を考慮すると, 次式より算出される。

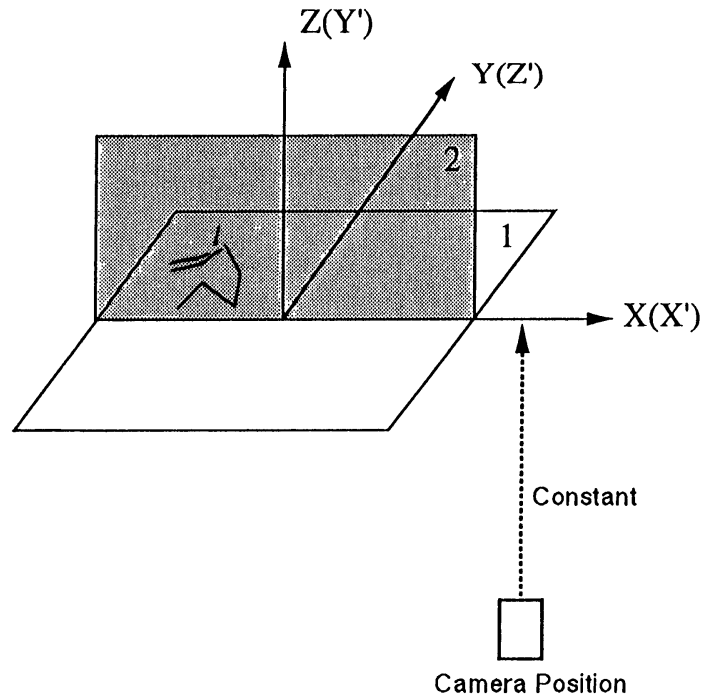

図 4 カメラとボートとの位置関係

$$
\begin{aligned}
& X=\left(Z^{\prime}-Z_{o}^{\prime}\right) \frac{a_{11} x+a_{21} y-a_{31} f}{a_{12} x+a_{22} y-a_{32} f}+X_{o}^{\prime} \\
& Y^{\prime}=\left(Z^{\prime}-Z_{o}^{\prime}\right) \frac{a_{13} x+a_{23} y-a_{33} f}{a_{12} x+a_{22} y-a_{32} f}+Y_{o}^{\prime} \\
& \text { ここに, } X_{o}^{\prime}, Y_{o}^{\prime}, Z_{o}^{\prime} \text {; カメラの位置, }
\end{aligned}
$$

困 5 はバウ波よけ先端, 踵およびシート部分の鉛直 方向の時間変位を示したものである。困 5 より船の上 下動が理解される。図 6 は船の水平方向に対する相対 速度および加速度を示したものである。四 7 から四 8 にバウおよび 2 番の各特徵点に対する時間変位を示 す。各特徵点の水平変位はバウ波よけに対する変位で あり，また鉛直変位はバウ波よけの鉛直方向の変位を 差引き船の上下動の影響を除いたものである。

なお,これらの図は 5 点平均により平滑化処理を施

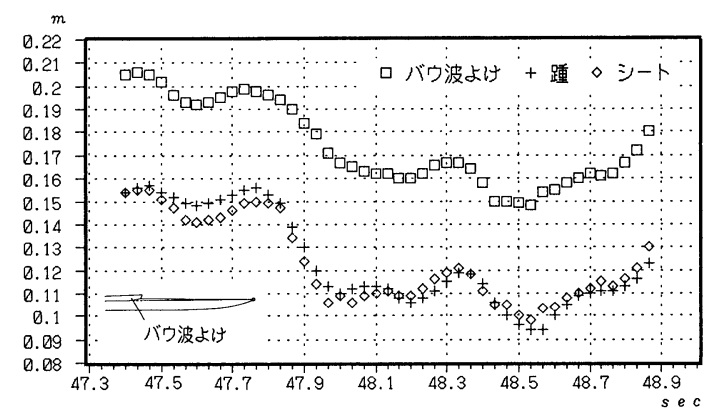

図 5 バウ波よけ，踵およびシートの鉛直変位 

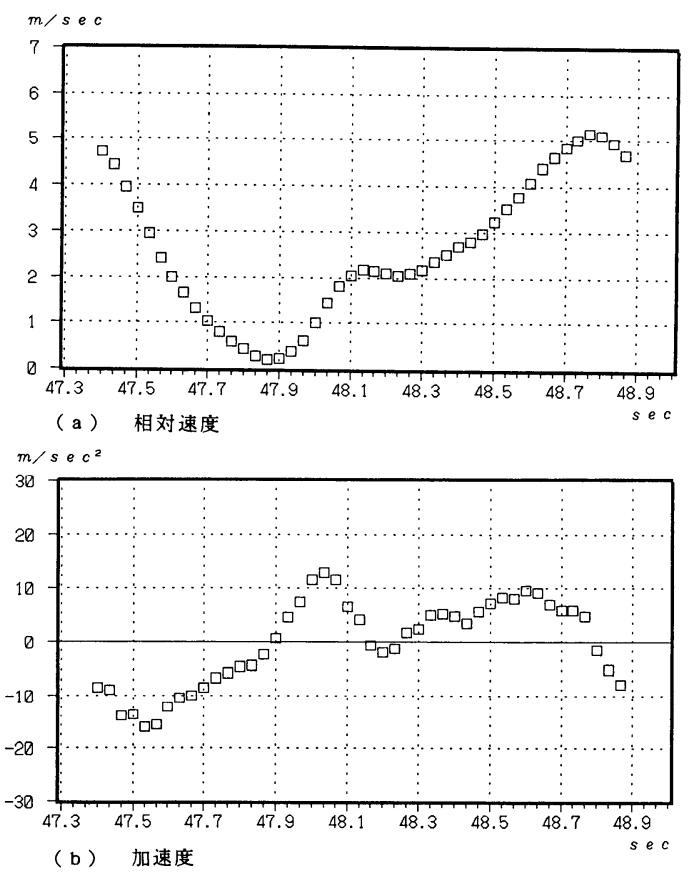

図 6 ボートの速度と加速度

した結果である。

\section{4. 動作 分 析}

キャッチ（漕ぎ始め）の瞬間を水面に接したオール のブレード（オール先端の偏平部）から水飛沫が上が る 1 コマ手前の画面およびフイニッシュ(漕ぎ終わり) の瞬間をブレードが水面から離れる画面とすると， 2 番のブレードの動きより各動作の瞬間は 3 分 47.8 秒 (キャッチ) および 3 分 48.4 秒 (フィニッシュ) となる。 したがって，一本中におけるストローク（ブレードが 水中にある時間）とフォワード（ブレードが空中にあ る時間)との比率は $1: 1.5$ となる。また，この時点に おけるストロークの強さはピッチ40の力漕と分析され る。

図 9 は頭, 肩, 肘, グリップ(握り部分), 背中, 膝 およびシートの一本中のバウおよび 2 番の動きの軌跡 を示したものである。なお，これらの軌跡は踵を原点 としたものであり，肘およびグリップについてはイン ボード (オール後端) 側ではバウの左腕と 2 番の右腕, アウトボード（オール前端）側ではバウの右腕と 2 番 の左腕との比較を行なった。

図 9 よりバウの膝掞よびシートのレンジ(移動範囲)
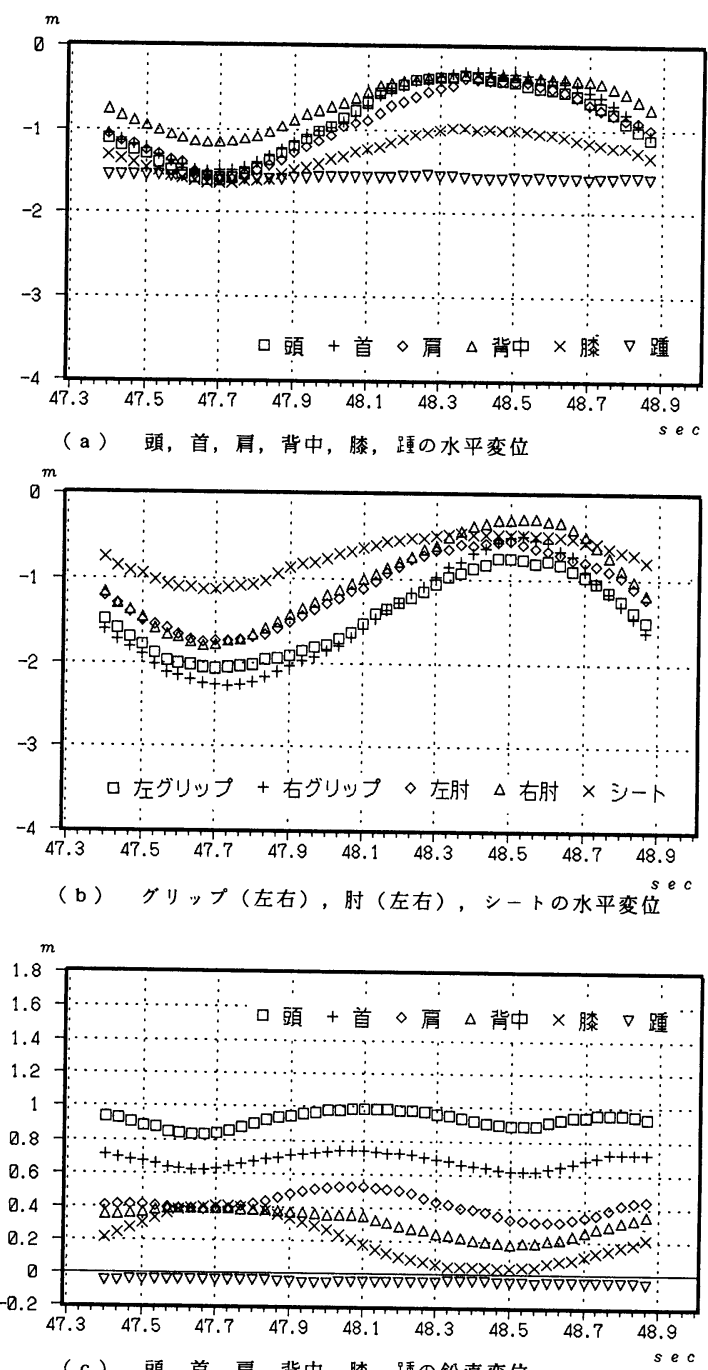

（c）頭，首，肩，背中，滕，踵の鉿直変位

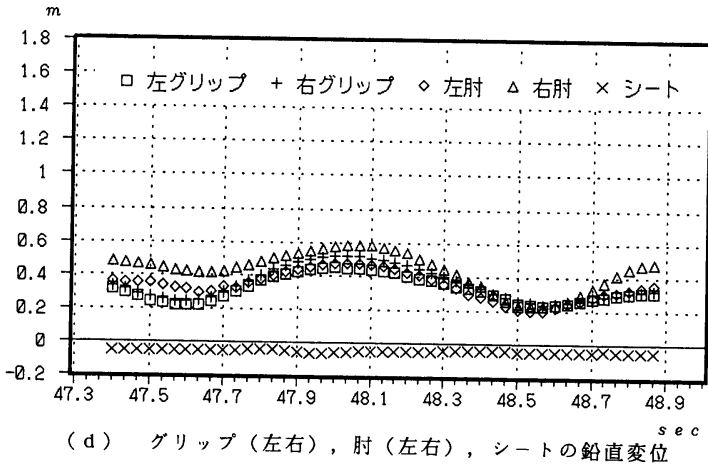

図 7 特徴点の時間変位（バウ）

は 2 番に比べて短く, 逆にグリップ, 肘, 頭, 肩およ び背中に対するレンジは大きく，バウは上体の前傾・ 後傾を大きく, 背中を湾曲させ，体のもたれを大きく 


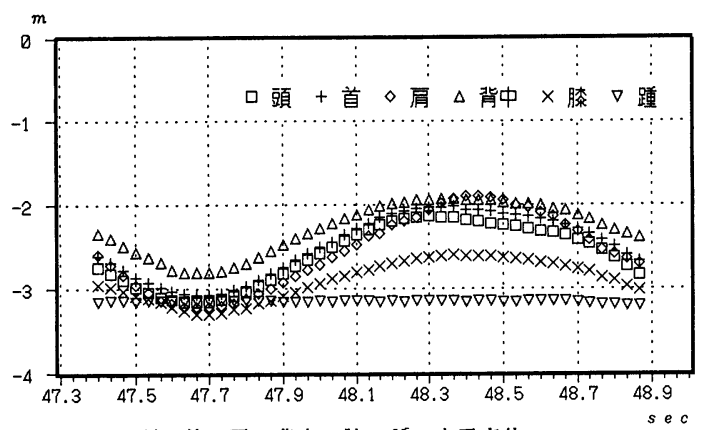

(a) 頭, 首, 肩, 背中, 滕, 踵の水平変位

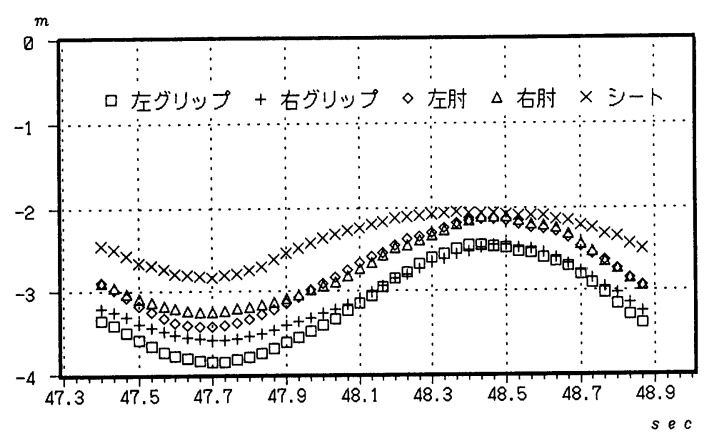

(b) グリップ（左右）, 时（左右）, シートの水平変位

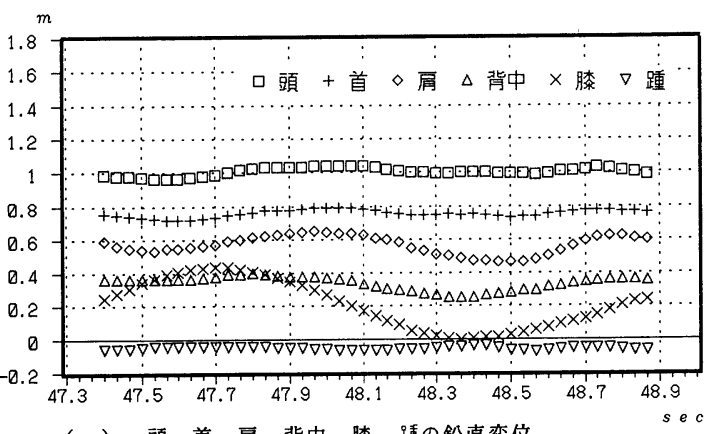

（c）頭, 首, 肩, 背中, 滕, 踵の鈶直変位

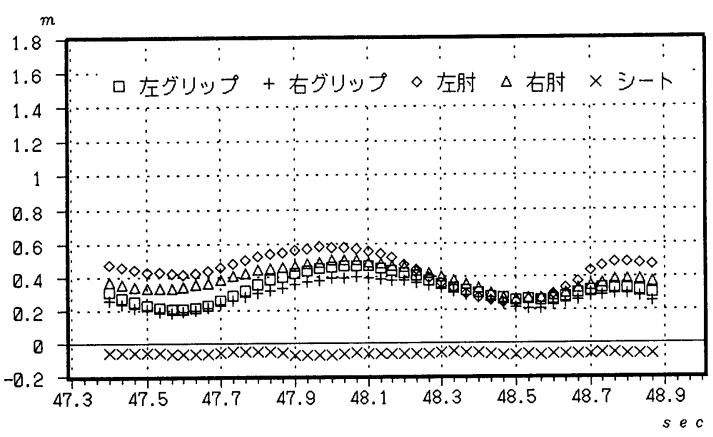

（d）グリップ（左右）, 时（左右）, シートの鈶直変位

図 8 特徵点の時間変位（2 番）

取った漕法を採っていることが理解される。また,フィ ニッシュ後のハンズアウェイ（両腕の移動）もバウお よび 2 番の各グリップは前方やや上に向かい理想的な

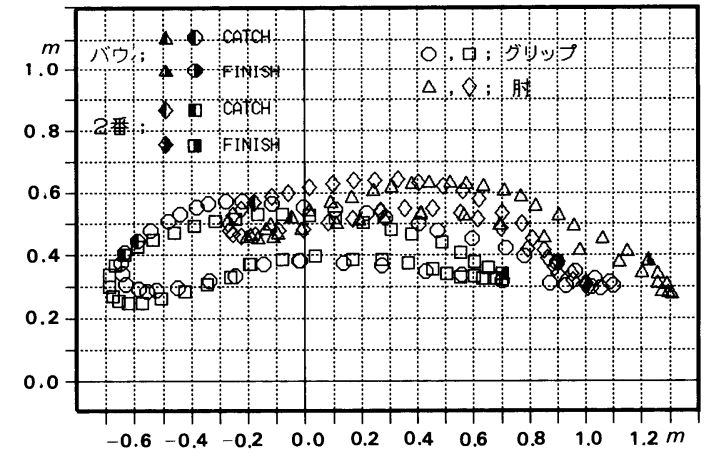

(a) グリップ, 时（インボート側）

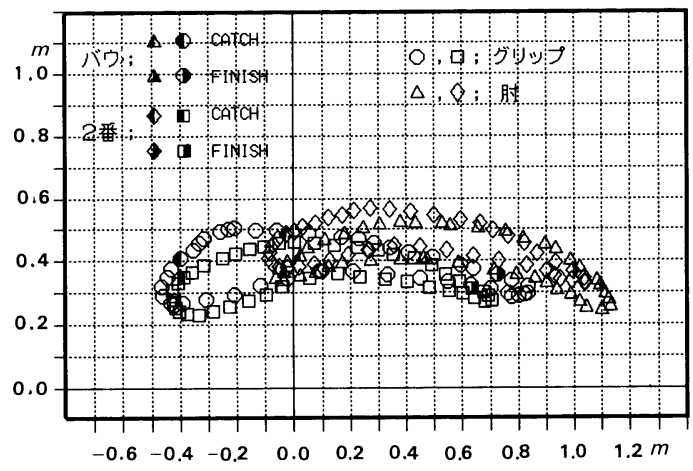

（b）グリップ，肘（アウトボート㑡）

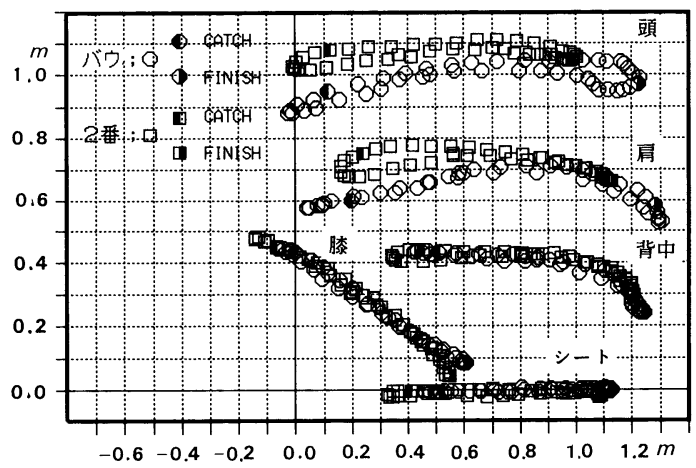

(c) 頭, 肩, 背中, 膝, シート

図 9 特徴点の軌跡

動きを示している。

図11は図10に拀けるバウと 2 番に対する角 $\alpha, \beta$ の 時間変位を示したものである。図11においてもバウは 背中を湾曲させて前傾・後傾を大きく採っていること が分かる。また，バウ， 2 番ともに最大前傾角 $(47.633$ 秒）付近においてすねが最も鉛直に近い漕法姿勢とな り，脚の開きと体の開きが同時に進行している。バウ はフォワード後半のシートレンジの短さを上体の前傾 により，フォワード前半のグリップレンジの大きさを 


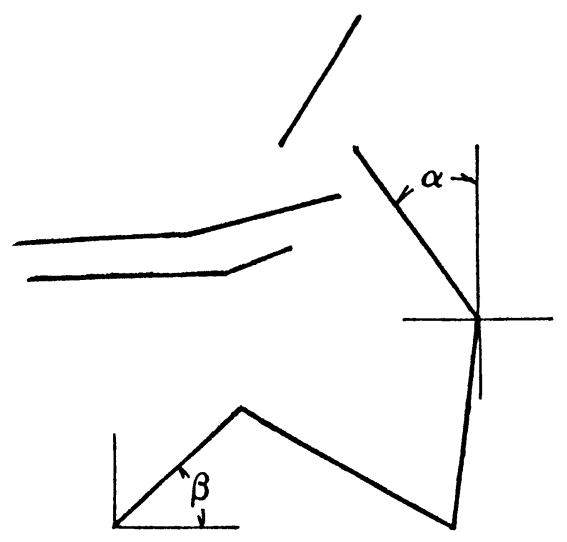

図10 漕法姿勢
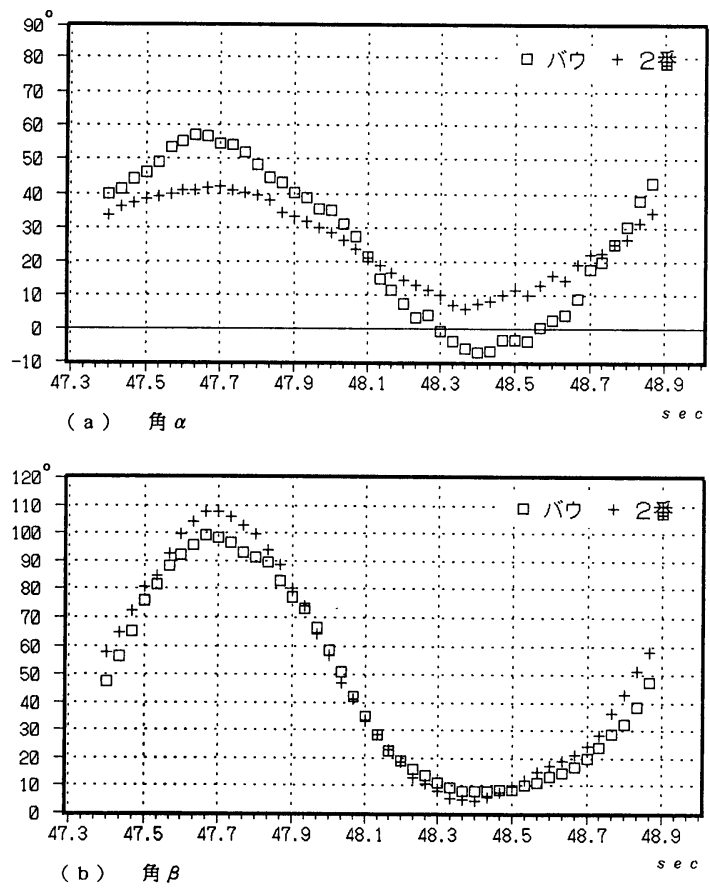

図11 漕法姿勢の時間変位

体のもたれにより補っていると分析される。なお, キャッチ直前において 2 番の $\beta$ がバウに比べて大き いのは 2 番の膝は左腕に遮られているため抽出時に誤 差が含まれた結果と判断される。

一方，図12(a)は踵とグリップとの水平方向に対する 距離の変位からバウおよび 2 番のアウトボード側にお けるグリップ速度を示したものである。ミドル中間か らフィニッシュ直後にかけてバウは 2 番より早いグ リップ操作を行ないレンジの大きさを補っていると理 解される。四12(b)はシートの水平方向の速度を示した ものである。なおキャッチ（47.8秒）と同時に各水平 速度の減少が認められる。

バウは上体の前傾・後傾を大きく取り，レンジを長 くした漕法であり，2 番は上体の摇れを小さく取り， 脚を中心にした漕法とボ一ト漕法における代表的な二 つの漕法姿勢9)の典型的な特徵を示した例と思われ る。
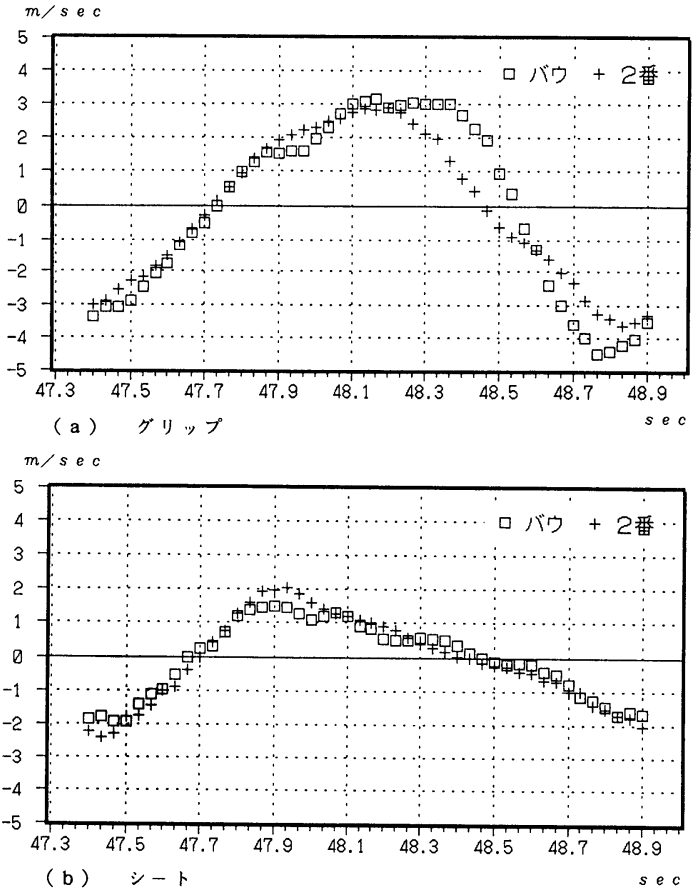

図12グリップとシートの速度

\section{5. シミュレーション}

各特徴点の動きの視覚化はボート漕法のトレーニン グにおいても有効な方法である。本研究ではバウと 2 番の動きをスティクモデルにより再現し, 一本分の動 きを百本繰り返すシミュレーターを作成した。本シ ミュレーターは次の 3 つの選択項目からなり，表示対 象をバウ， 2 番および両者の 3 通りの選択ができる他， ストロークの強さも 3 段階用意した。

1. 百本分の連続的スティクモデルの表示

2 . 一本分の各特徵点の軌跡の表示

3. 一本分の連続スティクモデルの表示

またキャッチ時およびフィニッシュ時には信号音 
が発生され，ディスプレイ上ではスティクモデルの色 が変わる等聴覚的にも視覚的にもトレーニングに有効 な環境とした。

眓13は両者を選択した場合の上記 3 項目の表示例で あり（a)はローイング中のフィニッシュにおけるス ティクモデル, (b)は一本分における頭, 首, 肩, 背中, 肘 (左右), グリップ (左右), 膝およびシートを選択 した場合の各特徵点の軌跡，(c)は一本分の連続スティ

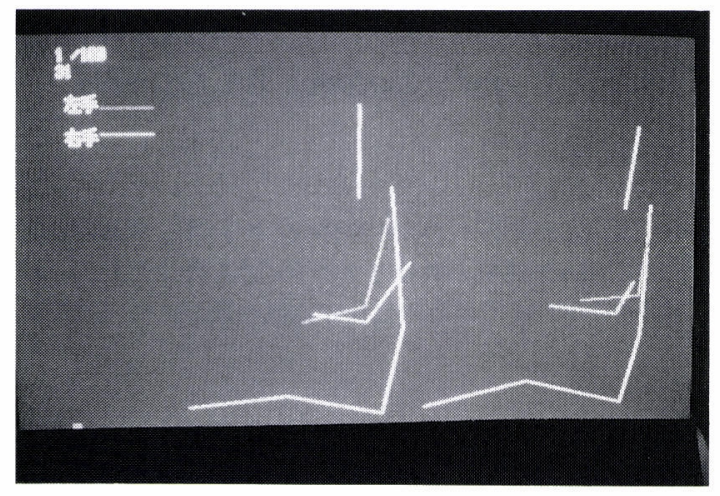

(a) フィニッシュにおけるスティクモデル

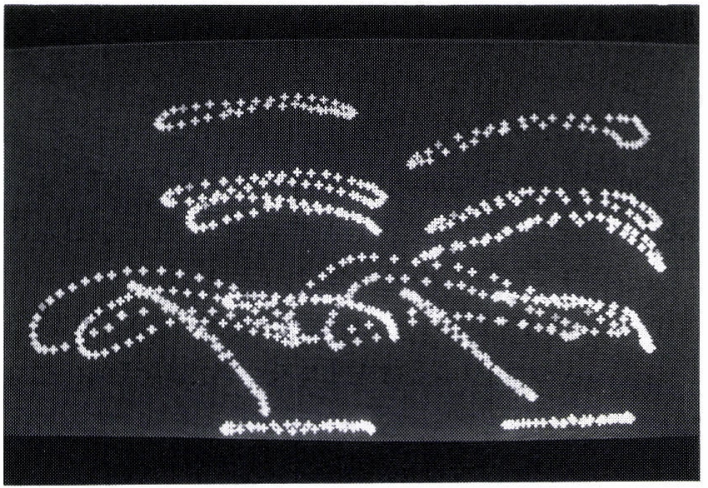

(b) 特徵点の軌跡

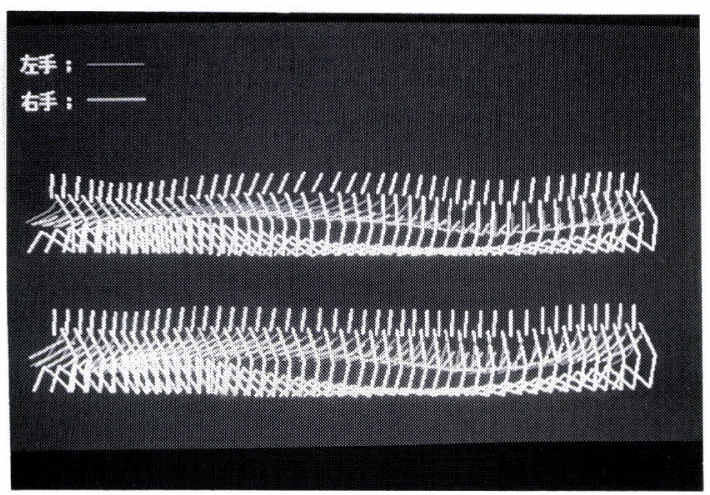

(c) 連続スティクモデル

図13 シミュレーター表示例
クモデルを表示したものである。

\section{5. 結論}

本研究ではビデオ画像を利用してバルセロナ・オリ ンピックでのエイト競技の動作解析を行なった。その 結果を以下に示す。

1）画面上に写し込まれているコースおよびコース 幅用のブイを基準点とすることによりカメラの標 定計算が可能となった。

2) バウおよび 2 番の漕法姿勢はボート漕法におけ る代表的な二つの姿勢の典型例であることが分析 された。

3 ）各特徴点の動きをスティクモデル化したシミュ レーターはボート漕法のトレーニングに有効な方 法であると思われる。

今後, ビデオ画像を利用した人体の動作解析のため には画像処理において特徴点の自動抽出システムが課 題と思われる。

(受付1993.3.2, 受理1993.5.11)

\section{参 考 文 献}

1) H. Chikatsu etc. : Sports Dynamics of Carl Lewis through $100 \mathrm{~m}$ race using Video imagery, 17th ISPRS, Com. 5, Washington. D.C., pp. 875-879, 1992.

2) M.K. Leung and Y-H. Yang: Human body motion segmentation in a complex scene. Pattern Recognition, Vol. 20, No. 1, pp. 55-64, 1987.

3 ) K. Akita : Image sequence analysis of real world human motion. Pattern Recognition, Vol. 17, No.1, pp. 73-83, 1984

4) T.W. Calvert: Goal-Directed, Dynamic animation of human walking, Computer Graphics, Vol. 23, No. 3, pp. 233-242, 1989.

5 ) W. Kinzel and E.D. Dickmanns: Moving humans recognition using spatio-temporal models, 17th ISPRS, Com. 5, Washington, D.C., pp. 885-892, 1992.

6 ）原島博他：次世代画像符号化の構想, 電子情報通信学 会技術研究報告, IE87-1, pp. 1-8, 1987.

7) T. Tsukiyama and Y. Shirai: Detection of the movements of persons from a sparse sequence of TV images. Pattern Recognition, Vol.18, pp. 207-213, 1985.

8) J.U. Baumann etc.: Photogrammetry in medical gait analysis, 17th ISPRS, Com. 5, Washington, D.C. pp. 464-468, 1992.

9 ) 須藤武幸：ボート競技, 講談社. 